Frédéric Jaëck (Aix Marseille Université) - Laurent Mazliak (Sorbonne Université) - Roman Murawski (Adam Mickiewicz University)

\title{
HOW FRENCH MATHEMATICIANS LEARNED ABOUT WHAT HAPPENED TO THEIR POLISH COLLEAGUES DURING WW2
}

\begin{abstract}
This article presents an exchange of letters between Wacław Sierpiński and Paul Montel during the year 1945. This correspondence, translated here into English, provides insight into how and in what form the French learned about the dramatic fate of many Polish mathematician colleagues during the war. We also give a short biography of the two protagonists, as well as some facts about the mathematicians mentioned in the letters.
\end{abstract}

Keywords: WW2, Montel, Sierpiński, Polish School of Mathematics.

\section{Introduction}

It is well known that after the First World War, Poland experienced a true golden age for mathematics ${ }^{1}$ thanks to the enthusiastic work of many scientists to whom the advent of the young independent state gave the opportunity to multiply daring research projects, particularly in logic, set theory, the theory of measure and functional analysis. The two decades of the interwar period saw an extraordinary efflorescence of fundamental work, driven by the creation of new journals such as Studia Mathematica or Fundamenta Mathematicae, which immediately took their place among the most highly rated journals. In the very recent book devoted to mathematical communities in the aftermath of the Great

- Address for correspondence: Roman Murawski, Faculty of Mathematics and Comp. Sci., Adam Mickiewicz University, Uniwersytetu Poznańskiego 4, 61-614 Poznań, Poland. Email: frederic.jaeck@math.cnrs.fr, laurent.mazliak@upmc.fr, roman.murawski@amu.edu.pl.

${ }^{1}$ See e.g. K. Kuratowski, Pół wieku matematyki polskiej (1920-1970), K. Kuratowski, A Half Century of Polish Mathematics ..., R. A. Beeler \& R. Norwood, Polish Mathematics in the First Half of the $20^{\text {th }}$ Century, R. D. Mauldin, The Scottish Book, R. Duda, Fundamenta Mathematicae ... \& R. Duda, Leaders of Polish mathematics between the two world wars. On the history of Poland one may consult N. Davies, God's Playground, S. Kieniewicz \& al., History of Poland, W. Reddaway \& al. (eds.), The Cambridge History of Poland, H. Roos, A History of Modern Poland ..., P. Wandycz, The Price of Freedom ... \& A. Zamoyski, The Polish Way ... . 
War - in which the three authors of the present article participated - two chapters are devoted to the Polish scene because of the truly exceptional rôle it played at that time ${ }^{1}$. The tragedy which played out during the Second World War is all the more striking: one can without exaggerating speak of an attempt at the annihilation of mathematical Poland. Reduced to ruins, as was the whole country by the German invasion and then the occupation and the fighting during the Soviet counter-offensive of 1944, the Polish mathematical community largely disappeared in the cyclone ${ }^{2}$.

This terrible story is well known and has been told many times in the past, and this article does not intend to convey any new information on this. However, it seems to us that not enough attention had been brought to the way in which one became aware of the Polish situation after 1945, where the mathematical community had forged solid and warm links with Polish colleagues ${ }^{3}$. Our recent rediscovery in the personal papers of the mathematician Paul Montel of an exchange with Wacław Sierpiński in the fall of 1945 makes it possible to better understand this point and, no doubt, to estimate the shock that the news must have produced on French mathematicians ${ }^{4}$.

This short article, after having recalled some biographical elements of the protagonists, presents the above-mentioned exchanges of 1945 in French (the original language of the exchanges) and their English translation. We hope that these moving documents can encourage further research on several lesserknown protagonists who disappeared in the disaster. Our short study would certainly deserve to be extended to take into account in a more general way how other Poles strongly linked with France (e.g. the mathematical chemist and mathematician Mieczysław Biernacki (1891-1959) quoted in Montel's letter as a friend - Montel had been his thesis adviser in the 1920s in Paris) recounted the tragedy experienced in their country after the war to their French counterparts.

\section{Short biographical elements}

\subsection{Wacław Sierpiński}

Wacław Franciszek Sierpiński was born on 14 March 1882 in Warsaw.

\footnotetext{
${ }^{1}$ See L. Mazliak \& R. Tazzioli (eds.), Mathematical Communities ... and, more especially, the two chapters on Polish mathematics: R. Murawski, Mathematics and logic ... \& F. Jaëck, From Fundamenta Mathematicae ... .

${ }^{2}$ One may consult e.g. R. Duda, Polish mathematicians ... and S. Domoradzki \& M. Stawiska, Polish mathematicians and mathematics in World War I. Part I ... \& S. Domoradzki \& M. Stawiska, Polish mathematicians and mathematics in World War I. Part II ... .

${ }^{3}$ One can mention here, for example, the collaboration of Jean Leray (1906-1998) with Juliusz P. Schauder. They developed a revolutionary method for establishing the existence of solutions to certain types of partial differential equations. The tool is now known as the Leray-Schauder degree. See J. Leray, My friend Julius Schauder \& J. Mawhin J., A tribute to Juliusz Schauder.

${ }^{4}$ The exchange between Sierpiński and Montel seems to be known to Hugo Steinhaus, one of the leaders of Polish mathematics, however the exact content of their correspondence was unknown to him. See H. Steinhaus, Mathematician for All Seasons, where he wrote under Oct. 28, 1945: Sierpiński showed me a letter he has received from Montel elicited by Sierpiński's summary of the losses to Polish mathematics occasioned by the war. Montel has brought the list to the attention of the French Académie des Sciences, and a decision has been taken to publish the list in their proceedings.
} 
During the years 1900-1904 he studied mathematics at Imperial University in Warsaw [Императорский Варшавский Университет; Cesarski Uniwersytet Warszawski], then a Russian institution, where he came under the influence of the great expert on number theory Georgij Feodosevich Voronoĩ (1868-1908). In 1904 Sierpiński received the degree of candidate of science and was awarded a prize (a gold medal) from the Department of Mathematics. He began then to teach in a secondary school. In 1905 he participated in the great strike in the schools ${ }^{1}$, then resigned and moved to Cracow, where he received his doctorate in 1906 from Jagiellonian University [Uniwersytet Jagielloński]. He returned to Warsaw and during the years 1906-1908 he was active as a teacher in secondary schools and in the so-called Society of Scientific Courses [Towarzystwo Kursów Naukowych], an unofficial Polish university. In the meantime, in 1907 he spent some months in Göttingen. In 1908 he was granted his habilitation at Jan Kazimierz University [Uniwersytet Jana Kazimierza] in Lvov ${ }^{2}$ and became an associate professor, then an extraordinary professor in 1910. His scientific interests moved from number theory to set theory ${ }^{3}$. He gave lectures on this topic (in fact this was one of the first lectures dedicated to set theory in the world) and wrote in 1912 a handbook entitled Zarys teorii mnogości [An Outline of Set Theory]. He also aroused young mathematicians' interest in set theory. Among them were Zygmunt Janiszewski (1888-1920), Stefan Mazurkiewicz (1888-1945) and Stanisław Ruziewicz (1889-1941).

As a professor at the state university in Lvov, Sierpiński was forced to take Austrian citizenship. At the beginning of the First World War he was sent by the Russian authorities - as an Austrian citizen - to an internment camp in Wiatka near Moscow. Thanks to the help of his Russian colleagues, he was able to move to Moscow, where he collaborated with Nikolaj Nikolaevich Lusin [Николай Николаевич Лузин] (1883-1950) and learned about the theory of analytic sets which was developed there by Lusin and his collaborators and students. In the future he appeared to be one of the most important persons in the development of the new domain of set theory called descriptive set theory.

\footnotetext{
${ }^{1}$ It was a strike of Polish youth initiated by students of the university and technical university in Warsaw. It began on $28^{\text {th }}$ Jan. 1905 as a reaction to the so-called Bloody Sunday or Red Sunday[Кровавое воскресенье] in St Petersburg on $22^{\text {nd }}$ Jan. [ $9^{\text {th }}$ Jan. o.s.] 1905. The first reaction of the authorities was the temporary closing of schools. With time the strike extended to secondary schools in Warsaw and many towns of the Russian partition. Solidarity strikes took place also in the Prussian partition, where they were a protest against Germanization.

${ }^{2}$ As is well known, the toponymy of this part of Eastern Europe is a complex problem as cities were often designed under different names by the different communities that lived there, and the changes in the political map after the Great War implied changes in the official denominations. For simplicity, in the present paper we adopt a unique designation for each town, corresponding to its modern English name. Lvov corresponds to the Polish Lwów as well as to the Ukrainian Lviv and to the German Lemberg. Warsaw corresponds to the Polish Warszawa. Cracow to the Polish Kraków and the German Krakau. Vilnius to the Polish Wilno and German Wilna.

${ }^{3}$ The decisive moment was his discovery that the plane and the line have the same number of points, that is points in the plane could be specified with a single coordinate. He wrote then to his colleague Tadeusz Banachiewicz (1882-1954), the future professor of astronomy of Jagiellonian University, who at that time studied in Göttingen, asking him whether this result was known. Banachiewicz answered the question sending a telegram containing the unique word: Cantor. In this way he called Sierpiński's attention to Cantor's works - which Sierpiński began then to study. See A. Mostowski, Travaux de W. Sierpiński ..., p. 9.
} 
In February 1918 Sierpiński returned to Lvov and during the fall of the same year he became a professor at the reborn Polish university in Warsaw, where he was offered a chair in mathematics. Janiszewski and Mazurkiewicz were already professors there so that three among the world's best specialists in set theory were gathered at Warsaw University. Janiszewski had postulated in the manifesto O potrzebach matematyki w Polsce [On the Needs of Mathematics in Poland] (1917) that the future scientific activity should be concentrated on one domain of mathematics (a natural candidate was precisely set theory and related domains like topology or the theory of real functions) and that a new mathematical journal should be created to support the research effort. Sierpiński played an important role in the realization of this program, becoming one of the creators and editors of the newly established (in the year 1920) journal Fundamenta Mathematicae, the first journal in the world devoted to a special mathematical topic.

The interwar period of time was one of the most creative periods in Sierpiński's scientific activity. He wrote many papers, among them a fundamental monograph Hypothèse du continu (1934) (in the series Monografie Matematyczne of which he was a co-founder), educated a huge number of students (it is sometimes said that almost every younger Polish mathematician was indirectly or directly Sierpiński's student), and was engaged in large-scale organizational work: organization of various international congresses and conferences, as well as collaboration with many scientific centres. He was also a member of the Warsaw Scientific Society, of the Board of the Polish Academy of Sciences and for a period was the President of the Polish Mathematical Society.

During the Second World War he continued his activity writing papers and new books as well as teaching in the underground university. After the Warsaw Uprising between August and October 1944, he was sent with tens of thousands of evacuees from Warsaw to Durchgangslager 121 (transit camp) in Pruszków. In February 1945 he came to Cracow, where he lectured at the Jagiellonian University. In the fall of 1945, Sierpiński was able to recover his former position in the University of Warsaw which he kept until his retirement in 1960. He was also one of founders of the newly established Institute of Mathematics of the Polish Academy of Sciences, which he chaired between 1953 and 1967.

After the Second World War Sierpiński's scientific interests were concentrated mainly on number theory. He wrote several papers and a monograph Elementary Theory of Numbers (1964). Between 1958 and 1969, he was the editor-in-chief of the re-established journal Acta Arithmetica ${ }^{1}$. However, he did not totally abandon set theory and published in particular a synthetic encyclopedic monograph Cardinal and Ordinal Numbers (1958, $2^{\text {nd }}$ ed. 1965).

As seen, Sierpiński was very active in various fields, especially number theory and set theory. The list of his publications includes more than 800 items,

\footnotetext{
${ }^{1}$ The journal was established in 1935 by Salomon Lubelski (1902-1941) and Arnold Walfisz (1892-1962). It was the third Polish mathematical journal - along with Fundamenta Mathematica and Studia Mathematica devoted to a specific domain of mathematics - in this case to number theory. Before WW2, three volumes were published. The journal was re-established in 1958.
} 
among them several dozen books. He had also an important teaching and organizational activity. His contributions were celebrated on the domestic and international scene, as proved by the attribution of several doctorates honoris causa, from the universities in Amsterdam, Bordeaux, Lvov, Moscow, Paris, Prague, Sofia, Tartu, as well as his election as a foreign member of several academies of sciences. When he died on $21^{\text {st }}$ October 1969 in Warsaw, he was a true symbol of the rebirth of the Polish mathematical school after WW2. Kuratowski published in 1972 a nice obituary about his deceased colleague ${ }^{1}$. One of the main scientific awards granted by the Polish Mathematical Society [Polskie Towarzystwo Matematyczne] is named after Sierpiński, and he is on one of the four stamps representing Polish mathematicians printed by the Polish Post Office. Moreover, every year the University of Warsaw awards the Sierpiński Medal to a distinguished mathematician.

\subsection{Paul Montel}

Born in Nice, Paul Montel (1876-1975) belongs to the brilliant school of mathematical analysis existing in France at the turn of the $20^{\text {th }}$ century with the names of Picard, Hadamard, Borel, Lebesgue and others ${ }^{2}$. He researched mostly the holomorphic functions in complex analysis. His most famous contribution was the introduction and systematic development of the notion of normal family of complex functions he had introduced in his PhD defended in 1907. In 1911 he obtained a first place, maitre de conférences, at the University of Paris. The mathematicians Pierre Fatou and Gaston Julia worked also on complex analysis in relation to problems of holomorphic dynamics and this led to some tensions in 1918 when the Great Prize of Paris Academy of Science was attributed to Julia $^{3}$.

Montel was nominated full professor at the Sorbonne in 1922, first to the chair of general mathematics then to that of rational mechanics. In 1934 the 41year old Julia was chosen by the Paris Academy of Sciences as Painlevé's successor despite the fact that Montel had previously been selected by the members of the mathematical section. As Audin explains, Julia's terrible wound received during WW1 probably explains this unusual procedure. During all this period, Julia was always put forward by senior scholars as a display of the sufferings and the resilience of French science in the conflict. This circumstance considerably accelerated his career ${ }^{4}$. This delayed election of Montel did not help in improving the relations between him and Julia which remained tense until

${ }^{1}$ See K. Kuratowski, Wactaw Sierpiński (1882-1969). Paul Montel published a necrology of Sierpiński in 1970. See P. Montel, Notice nérologique sur Waclaw Sierpinski.

${ }^{2}$ For more details on Montel's life, esp. his links with his native town, see L. de Broglie \& al., Paul Montel, mathématicien niçois. See also H. Gispert, La France mathématique, H. Gispert \& J. Leloup, Des patrons des mathématiques en France dans l'entre-deux-guerres \& Ch. Charle \& E. Telkes, Les professeurs de la Faculté des sciences de Paris...

${ }^{3}$ This point immediately helped Julia to gain an international visibility as is seen in the announcement by the journal Nature on Dec. 26, 1918. For more details on the complex relations between Fatou, Julia and Montel see M. Audin, Fatou, Julia, Montel ... .

${ }^{4}$ See M. Audin, Fatou, Julia, Montel ..., pp. 203 ff. 
Montel's death in $1975^{1}$. In 1937, Montel was elected to the Paris Academy of Science.

Between the two world wars, Montel exerted a major influence, in particular to help young students (such as Szolem Mandelbrojdt after his arrival from Poland ${ }^{2}$ ) and entertained deep relations with mathematicians from Central and Eastern Europe.

The first letters from Sierpiński to Montel were written in the 1930s. In fact, Sierpiński tried to convince Montel to come to Poland. This occurred in June 1935, when Montel received a doctorate honoris causa from Warsaw University (the same distinction was awarded a few years before to Borel) and gave several talks in Lvov and Warsaw about functions of one or several complex variables [fonctions univalentes et multivalentes]. A talk for a more general audience was given at the Warsaw Science Society [Towarzystwo Naukowe Warszawskie] in the Staszic Palace, co-organized by the Institut Français. This Polish trip was the occasion for Montel to meet a lot of members of the dynamic Polish mathematical community who welcomed him with great enthusiasm.

In 1936, Montel was invited to read a cycle of lectures at Sofia University by Nikola Obrechkoff and in 1938 the Romanian mathematician Petre Sergescu organized in Cluj a great international meeting in honour of Montel who was again treated as a hero.

Then came the war. During the first months Montel was head of a FrenchBritish scientific mission. In 1941, he was chosen as dean of the Faculty of Science of Paris University and stayed at this position up to his retirement in 1946. This choice may surprise at first glance as Montel was considered as a moderate leftist, not really in line with the orientations of the Vichy regime, all the more important in occupied Paris, with deans appointed by the government. However, there was a consultative vote by the members of the Faculty of Science in 1941, whose majority chose Montel instead of other candidates much closer to Vichy or even the collaborationist milieux. This vote thus expressed a certain spirit of resistance and the education minister Jérôme Carcopino (1880 1970), a renowned historian close to the Vichy regime but concerned with academic independence, skilfully accepted to follow the result and chose Montel as a dean in 1941. This attracted some hateful comments from the collaborationist press:

The election of the dean of the faculty of science was organized according to the republican tradition. At the first selection, an overwhelming majority was given to the noble Darmois, an eminent physicist and mathematician, an opponent of the sad Perrin, remembered as a warm supporter of the front popu! $!^{[3]}$ So, in order to

\footnotetext{
${ }^{1}$ See e.g. M. Barbut, B. Locker \& L. Mazliak, Paul Lévy and Maurice Fréchet ..., p. 214.

${ }^{2}$ See S. Mandelbrojt, Notice nécrologique sur Paul Montel, which contains a discussion of his work in function theory, emphasizing his contributions to the study of normal families.

${ }^{3}$ Front рори is an allusion to the Front Populaire, the leftist alliance between socialists, communists and radicals that acceded to power in France in 1936, under the direction of the President of the Council, that is to say Prime Minister, Léon Blum (1872-1950). It was a basis of collaborationist and Vichy propaganda to attribute the
} 
have the mixed-blood Montel ${ }^{[1]}$ appointed, Borel ${ }^{[2]}$,

helped by Carcopino's grace [...], was sent to collect the wishes and voices of all the little personnel in the most discreet places of the venerable house. ${ }^{3}$

The Darmois mentioned in this quote was the physicist Eugène Darmois (18841958 ), brother to the mathematician Georges Darmois (1888-1960) who, contrary to Eugène, spent the war in London in service of de Gaulle. Montel in fact managed to get through this dark period by avoiding any overly compromising arrangement with the Vichy regime or the occupier, as evidenced by many testimonials of sympathy issued after the Liberation, and above all by the fact that he could continue his mandate as a dean until his retirement in 1946, a quite rare event among those who were in charge of important administrative functions during the German occupation ${ }^{4}$.

\section{The 1945 exchanges}

We now transcribe four letters ${ }^{5}$ : Sierpiński's letter to Montel on September $27^{\text {th }}$, Montel's answer on October $13^{\text {th }}$, and an exchange between Montel and the Polish ambassador in France ${ }^{6}$ on the same topic. Short Biographical Endnotes are provided with their English translation. The first letter reproduced here, sent by Sierpiński in September 1945, was presented before the French Académie des sciences by Montel on the $8^{\text {th }}$ of October, and was inserted in the Comptes rendus printed on the $1^{\text {st }}$ of January $1946^{7}$.

French collapse of 1940 to the 1936 political turn, along with harsh anti-Semitic attacks against Blum.

${ }^{1}$ Montel had no Jewish ancestry at all, but the collaborationist press did not bother with such details when it came to destroying someone's reputation.

${ }^{2}$ Emile Borel himself met with some great troubles during the Occupation of France. He was arrested by the Gestapo, along with some other Academicians, and detained in jail for a month in November 1941. See L. Mazliak \& G. Shafer, What does the arrest ... .

${ }^{3}$ See M. Audin, Fatou, Julia, Montel ..., , p. 197

${ }^{4}$ For complements about Montel's activity in the aftermath of WW2, see L. Mazliak, A whole new vigor ... .

${ }^{5}$ Those letters are in: Archives de l'Académie des Sciences, Paris: 72J15.94/8 (Cracovie, 27 September 1945: Letter from W. Sierpinski to Paul Montel), 72J15.94/9 (Paris, 13 October 1945: Letter from Paul Montel to the Polish ambassador), 72J15.94/10 (Paris, 13 October 1945: Letter from Paul Montel to W. Sierpinski), and 72J15.94/11 (Paris, 22 October 1945: Letter from the Polish ambassador to Paul Montel). It should be added that the documents are the drafts of Montel's letters and the originals of the letters that he received.

${ }^{6}$ At that time the Ambassador was Stanisław Skrzeszewski, who took office in France in October 1945. He held a PhD in philosophy. During his studies, from 1921, he belonged to Communist youth circles, and later to the Communist Party of Poland. Arrested in 1924, he was released thanks to Władysław Heinrich's intervention, a professor of psychology. Not accepted for work at the university, he left for France, where he studied philosophy and general methodology at the Sorbonne from 1925 to 1926 . There he maintained contacts with the French Communist Party, but he did not display much political activity. In 1944 he headed the Education Department of the Polish National Liberation Committee, and between 1944 and 1945 was Minister of Education. Between 1945 and 1947, he was Polish ambassador to France, and between 1947 and 1950, again Minister of Education. 2021].

${ }^{7}$ The text is available online at https://gallica.bnf.fr/ark:/12148/bpt6k3173p/f389 [retrieved on Feb. 24, 
3.1. Letter from Wacław Sierpiński to Paul Montel

Cracovie, le [crossed out: 15 Avril] 27 septembre 1945

rue $S w$. Tomasza 30, m. 7

Mon cher Collègue et Ami,

Il m'était impossible d'écrire à Vous pendant les derniers 5 et demi années qui étaient tragiques pour l'école mathématique polonaise.

Les mathématiciens polonais nommés plus bas ont été assassinés par les Allemands pendant leur occupation de notre pays:

Stanisław Ruziewicz, en 1939, Recteur de l'Académie de Commerce à Lvov, ancien professeur de l'Université de Lvov, tué par le Gestapo à Lvov en Juillet 1941,

Antoine Eomnicki, en 1939, Prorecteur de l'Ecole Polytechnique de Lvov, tué par le Gestapo à Lvov en Juillet 1941,

Wladimir Stożek, doyen de l'Ecole Polytechnique de Lvov, tué par le Gestapo à Lvov en Juillet 1941,

Casimir Bartel, professeur et ancien Recteur de l'Ecole Polytechnique de Lvov, tué par le Gestapo à Lvov en Juillet 1941

Antoine Hoborski, ancien Recteur de l'Académie des Mines à Cracovie, Professeur à l'Université de Cracovie, est mort en 1940 dans le camp de concentration de Sachsenhausen (près de Berlin), où il fut transporté en Novembre 1939 avec d'autres professeurs de l'Université de Cracovie, dont 17 sont également morts dans ce camp,

Stanisław Saks, chargé du cours à l'Université de Varsovie, tué par le Gestapo à Varsovie en 1943,

Alexandre Rajchman, professeur à l'Université libre de Varsovie est mort en 1940 au camp de concentration à Dachau,

Adolphe Lindenbaum, chargé du cours à l'Université de Varsovie tué en 1942,

J. P. Schauder, chargé du cours à l'Université de Lvov, tué en 1943,

H. Auerbach, chargé du cours à l'Université de Lvov, tué en 1943,

Jacob, chargé du cours à l'Université de Lvov, tué par le Gestapo à Varsovie en 1943,

Antoine Wilk, docteur en phil. qui a découvert plusieurs comètes portant son nom est mort à Cracovie en 1940 le lendemain de son retour du camp de concentration à Oranienburg. 
À cause des événements de guerre sont morts encore:

S. Dickstein, professeur d'Honneur de l'Université de Varsovie doyen d'âge des mathématiciens polonais, est mort en 1939 pendant une attaque aérienne,

Witold Wilkosz, professeur à l'Université de Cracovie est mort à Cracovie en 1943

Stefan Kempisty, professeur à Université de Wilno est mort en prison,

Antoine Przeborski, professeur à l'Université de Varsovie est mort en 1941, 1939

André Kozniewski, docteur en phil. est mort en

Stefan Kwietniewski, chargé du cours à l'Université de Varsovie est mort en 1940.

Nous déplorons encore la mort de Stanisław Zaremba, professeur d'Honneur de l'Université de Cracovie (en 1943), celle de Stefan Mazurkiewicz, prof. à l'Univ. de Varsovie, et celle de Stefan Banach, prof. à l'Univ. de Lvov.

Ce sont des pertes personnelles. Il est à souligner que les mathématiciens polonais assassinés, parfois cruellement, par les Allemands, ne cultivaient aucune politique: la seule raison de les tuer fut celle qu'ils étaient des savants polonais (et, en 4 cas - leur "race"). Dans le domaine d'autres sciences la situation est analogue.

Mais voici d'autres pertes irréparables.

Notre grande bibliothèque mathématique qui se trouvait rue Oczki 3 (au Séminaire Mathématique de l'Université de Varsovie) fut brulée. Les bibliothèques privées de tous les mathématiciens de Varsovie (la mienne, celle de MM. Mazurkiewicz, Kuratowski, Borsuk et autres) furent brulées, ainsi que nos maisons, pendant les mois août-octobre 1944. Plusieurs de nos manuscrits - résultats de notre travail pendant les années 1939-1944-sont perdus. Nous n'avons littéralement aucun livre, aucun tirage à part. En automne 1939 le volume 33 des Fundamenta Mathematicae était sous presse (à Cracovie) 7 feuilles (112 pages) furent imprimées, les 10 suivantes étaient composées. Le directeur allemand de l'imprimerie a détruit la composition de ces 10 feuilles, dont les manuscrits et les épreuves sont brulés, ainsi que les exemplaires des volumes 1-32 qui se trouvaient à Varsovie, ainsi que les exemplaires des volumes parus des Monographies 
Mathématiques. Il ne nous reste que quelques exemplaires de ces volumes qui étaient hors de Varsovie. $C$ 'est donc une catastrophe pour les Fundamenta Mathematicae et les Monografie Matematyczne.

Ma maison (rue Marszalkowska 73) fut brulée par les Brandkommandos à la fin d'octobre 1944 sans aucune raison stratégique, quelques semaines après l'évacuation de Varsovie de tous les habitants polonais. Le 2 octobre 1944 nous étions obligés de quitter Varsovie à pieds et marcher 15 kilomètres (où se trouvait le camp de distribution) sans pouvoir prendre de notre maison rien sauf ce qu'on pouvait porter à la main $^{[1]}$. Nous avons ainsi perdu tout notre avoir. Cela avait lieu après avoir passé deux mois dans la ville assiégée et continuellement bombardée par les Allemands.

Le Siège de la Société des Sciences et des Lettres de Varsovie - le palais Staszic - est brulé. Nos académies et nos universités furent fermées et pillées par les Allemands en 1940. Des centaines de nos professeurs universitaires sont morts, respectivement tués dans les camps de concentration. Il n'y a presque aucune famille en Pologne qui n'a perdu au moins un de ses membres tués ou martyrisés par les Allemands.

Provisoirement je me trouve avec ma femme à Cracovie et j'y resterai probablement quelques mois. Les Allemands furent obligés de quitter si rapidement Cracovie qu'ils n'avaient pas le temps de détruire la ville. Cracovie est l'unique ville universitaire de Pologne où l'on pourra recommencer immédiatement l'enseignement universitaire.

Veuillez agréer, mon cher Collègue et Ami, l'expression de mes sentiments les plus cordiaux.

\section{W. Sierpiński}

English translation

Cracow, [crossed out: April 15] September 27, 1945, św. Tomasza street 30, m. 7

My dear Colleague and Friend,

It was impossible for me to write to you during the last five and a half years which were tragic for the Polish mathematical school.

\footnotetext{
${ }^{1}$ See W. Tatarkiewicz, Etyczne podstawy rewindykacji i odszkodowań [Engl. transl. Ethical Grounds for Retribution and Compensation [1945]].
} 
The Polish mathematicians named below were murdered by the Germans during their occupation of our country:

Stanistaw Ruziewicz ${ }^{[\mathrm{a}][1]}$, in 1939, Rector of the Academy of Commerce in Lvov, former professor at the University of Lvov, killed by the Gestapo in Lvov in July 1941,

Antoine Eomnicki ${ }^{[\mathrm{b}]}$, in 1939, Pro-rector of the Polytechnic School of Lvov, killed by the Gestapo in Lvov in July 1941,

Wladimir Stozek ${ }^{[\mathrm{c}]}$, Dean of the Lvov Polytechnic School, killed by the Gestapo in Lvov in July 1941,

Casimir Bartel ${ }^{[\mathrm{d}]}$, professor and former Rector of Lvov Polytechnic School, killed by the Gestapo in Lvov in July 1941,

Antoine Hoborski ${ }^{[\mathrm{e}]}$, former Rector of the Academy of Mining in Cracow, Professor at the University of Cracow, died in 1940 in the Sachsenhausen concentration camp (near Berlin), where he was transported in November 1939 with other professors from the University of Cracow, 17 of whom also died in this camp,

Stanisław Saks ${ }^{[\mathrm{f}]}$, lecturer at the University of Warsaw, killed by the Gestapo in Warsaw in 1943,

Alexandre Rajchman ${ }^{[\mathrm{g}]}$, professor at the Free University of Warsaw died in 1940 at the concentration camp in Dachau,

Adolphe Lindenbaum ${ }^{[\mathrm{h}]}$, lecturer at the University of Warsaw, killed in 1942,

J. P. Schauder ${ }^{[\mathrm{i}]}$, lecturer at the University of Lvov, killed in 1943,

H. Auerbach ${ }^{[\mathrm{j}]}$, lecturer at the University of Lvov, killed in 1943,

$J_{a c o b}{ }^{[\mathrm{k}]}$, lecturer at the University of Lvov, killed by the Gestapo in Warsaw in 1943,

Antoine Wilk ${ }^{[l]}$, doctor of phil. who discovered several comets bearing his name died in Cracow in 1940 the day after his return from the concentration camp in Oranienburg.

Because of the war events also died:

S. Dickstein ${ }^{[\mathrm{m}]}$, Honorary Professor of the University of Warsaw, the oldest of Polish mathematicians, died in 1939 during an air attack,

\footnotetext{
${ }^{1}$ For Short Biographical Endnotes see below, pp. 46-51.
} 
Witold Wilkosz ${ }^{[\mathrm{n}]}$, professor at the University of Cracow, died in Cracow in 1943,

Stefan Kempisty ${ }^{[0]}$, professor at Wilno University, died in prison,

Antoine Przeborski ${ }^{[\mathrm{p}]}$, professor at the University of Warsaw, died in 1941, 1939,

André Kozniewski ${ }^{[\mathrm{q}]}$, doctor of philosophy, died in

Stefan Kwietniewski ${ }^{[\mathrm{r}]}$, lecturer at the University of Warsaw, died in 1940.

We also deplore the death of Stanistaw Zaremba ${ }^{[\mathrm{s}]}$, Honorary Professor at the University of Cracow (in 1943), Stefan Mazurkiewicz ${ }^{[\mathrm{t}]}$, professor at the University of Warsaw, and Stefan Banach ${ }^{[\mathrm{u}]}$, Professor at the University of Lvov.

These are personal losses. It should be emphasized that the Polish mathematicians murdered, sometimes cruelly, by the Germans, had no political activity: the only reason to kill them was that they were Polish scholars (and, in four cases - their "race"). In the field of other sciences the situation is similar.

But here are other irreparable losses.

Our large mathematical library which was located on 3 Oczki street (at the Mathematical Seminary of the University of Warsaw) was burnt down. The private libraries of all Warsaw mathematicians (mine, MM. Mazurkiewicz's, Kuratowski's ${ }^{[\mathrm{v}]}, B^{2}$ Borsuk' ${ }^{[\mathrm{w}]}$ and others) were burnt down, as well as our houses, during the months of August-October 1944. Several of our manuscripts - results of our work during the years 1939-1944 - are lost. We literally have no books, no reprints. In the fall of 1939, volume 33 of Fundamenta Mathematicae went to press (in Cracow), 7 sheets (112 pages) were actually printed, the next 10 were typeset. The German director of the printing house destroyed the composition of these 10 sheets, the manuscripts and proofs of which are burnt, as well as the copies of volumes 1-32 which were in Warsaw, as well as the copies of the published volumes of Mathematical Monographs. We only have a few copies left of these volumes which were outside of Warsaw. It is therefore a disaster for Fundamenta Mathematicae and Monografie Matematyczne.

My house (73 Marszalkowska street) was burnt down by the Brandkommandos at the end of October 1944 for no strategic reason, a few weeks after the 
evacuation of all Polish inhabitants from Warsaw. On October 2 1944, we were forced to leave Warsaw on foot and walk 15 kilometres (where the distribution camp was located) without being able to take anything from our houses except what we could carry in our hands. We thus lost everything we had. This happened after spending two months in the city under siege and continuously bombed by the Germans.

The Headquarters of the Society of Science and Letters in Warsaw - the Staszic Palace - is burnt down. Our academies and universities were closed and looted by the Germans in 1940. Hundreds of our university professors died or were murdered in concentration camps. There is hardly a family in Poland that has not lost at least one of its members, killed or martyred by the Germans.

Temporarily I am with my wife in Cracow, and I will stay there probably a few months. The Germans were forced to leave Cracow so quickly that they did not have time to destroy the city. Cracow is the only university city in Poland where university education can be resumed immediately.

Please accept, my dear Colleague and Friend, the expression of my most cordial feelings.

W. Sierpiński

\subsection{Letter from Paul Montel to Wacław Sierpiński}

13 octobre 1945

Paul MONTEL, Doyen de la Faculté des SCIENCES, Membre de l'Institut,

à Monsieur le Professeur SIERPINSKI Rue sw. Tomasza, 30, m. 7 CRACOVIE

Mon cher collègue et ami,

C'est avec un sentiment d'horreur que j'ai lu votre lettre. Tant de savants, dont beaucoup m'étaient connus personnellement, ont disparu en pleine production; tant d'œuvres scientifiques ont été anéanties; tant de chercheurs sont privés de leurs moyens de travail.

J'ai donné lecture de votre lettre à la séance de l'Académie des Sciences du 8 octobre dernier. L'académie a décidé qu'elle serait insérée dans ses Comptes-Rendus.

Au milieu de tant d'affliction, j'ai la joie de vous savoir vivants, Madame Sierpinska et vous, et ceux dont vous ne parlez pas que je suppose échappés à ce 
tourbillon de meurtres: les Steinhaus, Leja et mon élève et ami Biernacki de Poznan.

J'aimerais recevoir directement de leurs nouvelles.

J'espère que nous pourrons vous aider à reconstituer vos bibliothèques, en particulier les ComptesRendus de l'Académie des Sciences pourront vous être envoyés par plusieurs d'entre nous qui en ont des collections personnelles.

Écrivez-moi par l'ambassade de France si je peux vous aider en quelque manière.

Veuillez agréer l'expression de ma cordiale sympathie pour le deuil qui frappe la science polonaise, l'expression de mes hommages respectueux pour Madame Sierpinska et pour vous, mon cher collègue et ami, toute mon affectueuse amitié.

English translation

October 13, 1945

Paul MONTEL, Dean of the Faculty of SCIENCES, Member of the Institute,

to Professor SIERPIŃSKI sw. Tomasza Street, 30, m.7

CRACOW

My dear Colleague and Friend,

It was with a feeling of horror that I read your letter. So many scientists, of which so many were known to me personally, disappeared in full production; so many scientific works have been destroyed; so many researchers, have been deprived of their means of work.

I read your letter at the meeting of the Academy of Sciences on October 8. The Academy has decided that it would be included in its Proceedings ${ }^{[1]}$.

In the midst of so much grief, I have the joy of knowing that you and Mrs Sierpinska are alive, and suppose that those whom you do not mention have escaped this whirlwind of murders: the Steinhaus ${ }^{(\mathrm{x})}$, Leja ${ }^{(\mathrm{y})}$ and my student and friend Biernacki ${ }^{[\mathrm{z}]}$ from Poznan.

I would like to hear their news from them directly.

I hope that we can help you reconstitute your libraries, in particular the Proceedings of the Académie des Sciences can be sent to you by several of us who have personal collections thereof.

\footnotetext{
${ }^{1}$ See Comptes rendus hebdomadaires des séances de l'Académie des sciences 221, 15/1945, pp. 389-391 (the letter was read during the session of Oct. 8, 1945).
} 
Write to me through the French Embassy if I can help you in any way.

Please accept the expression of my cordial sympathy for the mourning which strikes Polish science, the expression of my respectful homage to Mrs Sierpińska and to you, my dear colleague and friend, all my affectionate friendship.

3.3. Letter from Paul Montel to the Ambassador of Poland to France, Stanisław Skrzeszewski

le 13 octobre 45

Paul MONTEL Doyen de la Faculté des SCIENCES, Membre de l'Institut,

à Monsieur l'Ambassadeur de POLOGNE.

Monsieur l'Ambassadeur,

J'ai reçu de Monsieur le professeur Sierpinski une lettre relatant les assassinats des savants polonais par les Allemands durant l'occupation et, singulièrement, des mathématiciens.

L'école mathématique polonaise si brillante depuis 25 ans, unie à l'école française par la communauté de doctrine et des liens personnels, est décimée au sens littéral de ce mot.

J'ai donné lecture à l'Académie des sciences, dans la séance du 8 octobre dernier, de la lettre de Monsieur le professeur Sierpinski, au milieu de l'émotion générale. Mes confrères ont décidé à l'unanimité l'insertion de cette lettre dans nos Comptes Rendus pour qu'il reste dans nos archives la trace durable de ce crime contre la pensée.

J'ai désiré vous en tenir informer et vous adresser les condoléances émues de la Faculté des Sciences de l'Université de Paris. Je vous adresse aussi ma réponse à la lettre de Monsieur le professeur Sierpinski en vous priant de vouloir bien la faire acheminer par la voie de la valise diplomatique.

Veuillez agréer, Monsieur l'ambassadeur, l'expression de ma très haute considération.

English translation

October 13, 45

Paul MONTEL Dean of the Faculty of SCIENCES, Member of the Institute, to the Ambassador of POLAND.

Mr Ambassador,

I received from Professor Sierpinski a letter relat- 
ing the assassinations of Polish scientists by the Germans during the occupation and, in particular, of mathematicians.

The Polish mathematical school, so brilliant for 25 years, united with the French school by the community of doctrine and personal ties, is decimated in the literal sense of the word.

I read the letter from Professor Sierpinski to the Academy of Sciences in the meeting of October 8, amid general emotion. My colleagues unanimously decided to insert this letter in our Proceedings so that the lasting trace of this crime against thought would remain in our archives.

I wanted to keep you informed and send you the heartfelt condolences of the Faculty of Sciences of the University of Paris. I am also sending you my reply to Professor Sierpiński's letter, asking you to send it by diplomatic pouch.

Please accept, Mr Ambassador, the expression of my highest consideration.

3.4. Letter from the Ambassador of Poland to France, Stanisław Skrzeszewski, to Paul Montel

Ambassadeur de Pologne

Paris, le 22 Octobre 1945

Monsieur le Doyen,

Vous avez bien voulu m'informer de l'impression profonde qu'a exercée sur l'ensemble des membres de l'Académie des Sciences la lecture de la lettre du professeur Sierpinski relative aux assassinats des savants polonais par les Allemands durant l'occupation.

Les sentiments que vous exprimez dans votre lettre à l'égard du corps savant polonais ne manqueront pas de toucher très vivement les intellectuels de mon pays. Je vous prie d'exprimer dès à présent à vos éminents confrères de la Faculté des Sciences de l'Université de Paris et de l'Académie des Sciences ma conviction que leurs condoléances et l'insertion de la lettre du professeur Sierpinski dans les Comptes-Rendus de l'Académie seront considérés comme une nouvelle preuve de l'éternelle amitié entre nos deux pays et un inoubliable geste de solidarité.

Veuillez agréer, Monsieur le Doyen, l'assurance de ma haute considération.

L'Ambassadeur de Pologne Stanisław Skrzeszewski 
English translation

Ambassador of Poland

Paris, October 22, 1945

Dean,

You have kindly informed me of the deep impression that the reading of Professor Sierpinski's letter concerning the assassinations of Polish scientists by the Germans during the occupation has made on all the members of the Academy of Sciences.

The feelings which you express in your letter with regard to the Polish scholars will not fail to touch the intellectuals of my country very deeply. I ask you to express now to your eminent colleagues of the Faculty of Sciences of the University of Paris and of the Academy of Sciences my conviction that their condolences and the insertion of Professor Sierpinski's letter in the Proceedings of the Academy will be considered as further proof of the eternal friendship between our two countries and an unforgettable sign of solidarity.

Please accept, Mr. Dean, the assurance of my highest consideration.

The Ambassador of Poland Stanisław Skrzeszewski

\section{Conclusion}

The exchanges above is yet another illustration of the terrible fate of Poland during WW2. The impact of this tragedy deeply affected mathematics worldwide, as Polish mathematicians had succeeded in developing a very productive and pioneering school of mathematics, particularly in logic, topology and functional analysis ${ }^{1}$. The shock suddenly broke the dynamics engaged in promoting international research and its disseminating through the foundation of new scientific journals and the intensification of exchanges with mathematicians of other countries ${ }^{2}$. In Sierpiński's letter, the names of the deceased are not only those of leading mathematicians but also of several less famous actors who carried out the revival of Polish mathematics and helped to give an unprecedented dynamism to teaching and research in Poland ${ }^{3}$.

In addition to the human losses, the war affected the entire structure of higher education and research. Many texts were lost forever, papers ready for publication were burnt, as the letters exchanged between Montel and Sierpiński testify. In this landscape of ruins, it is significant that some institutions established before the war were strong enough to survive and to resume the

\footnotetext{
${ }^{1}$ See R. Duda, Polish mathematicians ... for a general view of the history of Polish mathematics during the $19^{\text {th }}$ and $20^{\text {th }}$ centuries.

${ }^{2}$ See R. Murawski, Mathematics and logic ... \& F. Jaëck, From Fundamenta Mathematicae ... .

${ }^{3}$ On the Polish Mathematical Society and its influence, see R. Duda, One hundred years of the Polish Mathematical Society.
} 
production of high-level mathematics thanks to a desperate surge of energy from the survivors.

Although there was certainly personal correspondence between Polish mathematicians and their French colleagues, former students and friends during or just after the war, the publication in the Comptes Rendus of Sierpiński's letter remained a rather isolated official testimony of the impact of the war on the Polish mathematical community. Nevertheless, thanks to the widespread publication of the Comptes Rendus, the letter provided many French mathematicians with a first-hand account of the impact of the war on colleagues who were geographically distant but whose recent mathematical progress they knew. On the Polish side, several mathematicians used their articles in Polish journals just after the resumption of publications to mention the losses inflicted by the Nazis ${ }^{1}$.

\section{Short Biographical Endnotes}

${ }^{[a]}$ Stanisław Leon Ruziewicz (1889-1941). Between 1908 and 1913, he studied mathematics at Jan Kazimierz University in Lvov, and was a student of Sierpiński. In 1913, he defended his $\mathrm{PhD}$, and in 1918 his habilitation. He became a professor at the University in Lvov in 1925, then a professor of the Academy of Commerce in Lvov in 1935, and was rector in 1939. His main scientific interest was the theory of real functions.

${ }^{[b]}$ Antoni Marian Łomnicki (1881-1941). Between 1899 and 1903, he studied at the Philosophical Faculty of Jan Kazimierz University in Lvov. He defended his $\mathrm{PhD}$ in 1903, and in 1919 his habilitation. In 1918, he took part in the defence of Lvov and in 1919-1920 he was engaged in the Polish-Soviet war. In 1920, he became a professor of the Polytechnic School of Lvov, then dean and pro-rector. Author of many textbooks, he worked in the theory of functions and measure theory.

[c] Włodzimierz Stożek (1883-1941). Between 1901 and 1905, he studied mathematics and physics at Jagiellonian University in Cracow. He spent two years in Göttingen to follow Hilbert's lectures. Between 1908 and 1922, he was a teacher in a secondary school and a lecturer at the university in Cracow. In 1922, he defended his PhD and was recruited as a professor of the Lvov Polytechnic School. He worked mainly in mathematical analysis. He was killed by the Gestapo together with his two sons Eustachy and Emanuel.

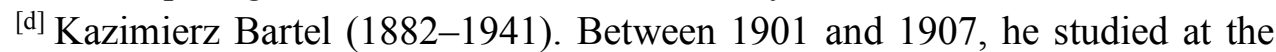
Lvov Polytechnic School. In 1908 and 1909, he studied mathematics and philosophy at Jan Kazimierz University in Lvov. In 1911, he defended a PhD at the Polytechnic School and in 1912 his habilitation in the same institution. Until 1940, he served in various positions (from assistant to professor) at the Lvov Polytechnic School. Bartel was politically active: he was a member of the Parliament between 1926 and 1930, served as Prime Minister in five govern-

\footnotetext{
${ }^{1}$ See e.g. Annales de la Societé Polonaise de Mathématique 18, 1945 \& 19, 1946, Fundamenta Mathematicae 33, 1945 \& B. Olszewicz, Lista strat kultury polskiej.
} 
ments and finally became a senator. He worked mainly in descriptive geometry. ${ }^{[\mathrm{e}]}$ Antoni Maria Hoborski (1879-1940). Between 1897 and 1901, he studied at the Jagiellonian University. Between 1901 and 1919, he was a teacher in secondary schools. He defended a PhD in 1908. Then he spent two years, 19081910, for a study sojourn in Paris and Göttingen. In 1912, he defended a habilitation in Cracow. In 1919, he was recruited as a professor of the Academy of Mining in Cracow (he was one of the main founders of this school and its first rector between 1920 and 1923). His works are mainly in differential and integral equations, projective and differential geometry, mathematical analysis, and also in mathematical education.

${ }^{[\mathrm{ff}]}$ Stanisław Saks (1897-1942). In 1915, he entered the Polish university in Warsaw, where he was a student of Mazurkiewicz. Between 1919 and 1921, he served in the Polish Army. In 1922, he defended a PhD, in 1926 a habilitation. Between 1921 and 1939, he was an assistant at the Polytechnic School in Warsaw, since 1926 a Privatdozent at the University of Warsaw. In 1940-1941, he was recruited at the Ukrainian University in Lvov. In 1942 he returned to Warsaw, was arrested in a train, and killed in November 1942. His works deal with mathematical analysis, function theory and functional analysis.

[g] Aleksander Rajchman (1890-1940). He studied mathematics in Paris, obtaining the licence ès sciences degree in 1910. After his return to Poland in 1919 he became an assistant at Warsaw University. In 1922, he defended a PhD and in 1925 a habilitation. Until 1938 he lectured at Warsaw University. In 1922, he began lectures at the Free University of Warsaw. Arrested by the Gestapo in April 1940, imprisoned in the Sachsenhausen concentration camp, he died probably in Oranienburg in July or August 1940. His works are in real analysis, in particular Fourier series, and also in probability and mathematical statistics.

${ }^{\text {[h] }}$ Adolf Lindenbaum (1904-1941). Between 1922 and 1926, he studied mathematics at the University of Warsaw. In 1928, he defended a PhD and in 1934 a habilitation. Since 1935, he was an assistant professor at Warsaw University. After the outbreak of the war, he went to the zone occupied by the Soviet Union as a consequence of the German-Soviet Pact of August 1939. He was in Vilnius in September 1939 and then in Bialystok, where he worked at the Pedagogical Institute organized by the Soviets. He was arrested in 1941 by the Germans, transported to Vilnius, and killed in 1942. His works deal with mathematical logic, set theory, the theory of functions, measure theory, topology, geometry, and real analysis. Lindenbaum was one of main representatives of the LvovWarsaw Philosophical School and the Warsaw School of Logic, and a close collaborator of Alfred Tarski. It is worth mentioning here also his wife Janina Hossiasson-Lindenbaum (1899-1942), who was one of the prominent women logicians in Poland. She did not hold an academic position, but was a mathematics teacher in one of Warsaw's high-schools. She was killed by the Gestapo in Vilnius in 1942. 
${ }^{[i]}$ Juliusz Paweł Schauder (1899-1943). After his graduation from secondary school, he was drafted into the Austrian army and sent to the Italian front, where he was captured and subsequently imprisoned in Italy. He came back to Poland with the Haller army (the Polish military contingent created in France in June 1917 to fight at the side of the Entente). Between 1920 and 1924, he studied mathematics at the Jan Kazimierz University in Lvov. In 1924, he defended his $\mathrm{PhD}$. Between 1925 and 1939, he was a teacher in various secondary schools. In 1927, he defended his habilitation, and then began as a lecturer at Lvov University. In 1932, he was granted a Rockefeller scholarship and spent one year in Leipzig and Paris. During the Soviet occupation of Lvov between 1939 and 1941, he was a professor of the Ukrainian University. After the German invasion, he went into hiding, but was arrested in the street in September 1943 and imprisoned. He was killed by the Germans probably in October 1943 during an attempt to escape. His works are mainly in functional analysis but also in topology, differential equations, and the theory of real functions.

${ }^{[j]}$ Herman Auerbach (1901-1942). Between 1921 and 1926, he studied at the Jan Kazimierz University in Lvov (first he studied law, and in 1922 he changed to mathematics). In 1930, he defended a $\mathrm{PhD}$, in 1935 a habilitation. He became lecturer at the University in Lvov. During the Soviet occupation, he was a professor of the Ukrainian University. He died in August 1942: according to some sources he committed suicide, according to other ones, he was killed by the Germans. His works deal with the theory of real functions, geometry and probability.

${ }^{[\mathrm{k}]}$ Marian Mojżesz Jacob (1900-1944). He was fascinated by the ideology of Zionism and spent his youth in Palestine before returning to Europe to study mathematics. In 1925, he defended his $\mathrm{PhD}$ at Vienna University. He then worked as an actuary in Trieste (Assicurazioni Generali) and later in Warsaw. During the years 1939-1941 he was a professor in the Chair of Probability Calculus at Ukrainian University in Lvov. After the German invasion and the beginning of the extermination of the Jews, he tried to save himself by working in the so-called Organisation Todt. In 1944, he left for Warsaw, where he died in unknown circumstances.

${ }^{[1]}$ Antoni Wilk (1876-1940). Between 1899 and 1906, he studied at the Jagiellonian University, where he received a doctor's degree for his dissertation on the Moon. Until 1912, he worked as a secondary school teacher in Tarnów, then in Krakow. On 6 November 1939, he was arrested and imprisoned in Wrocław and on 28 November 1939 together with other scientists he was transported to the Sachsenhausen camp near Oranienburg, from where he was released after three months, on 8 February 1940. He died on 17 February 1940 in Cracow.

${ }^{[\mathrm{m}]}$ Samuel Dickstein (1851-1939). He studied between 1866 and 1869 in the Main School and between 1869 and 1870 at the Imperial University of Warsaw. From 1870, he worked as a teacher of mathematics in various gymnasiums and in the Leopold Kronenberg School of Economics. Between 1878 and 1888, he ran his own Realschule. After the opening of the University of Warsaw as a 
Polish institution in 1915, Dickstein was appointed as a professor of mathematics and in 1919 as a honorary professor. He lectured mainly on algebra and the history of science. He also co-founded the series Biblioteka Matematyczno-Fizyczna [Mathematical-Physical Library] and the journal Prace Matematyczno-Fizyczne [Mathematical-Physical Works]. In 1887, he initiated Wiadomości Matematyczne [Mathematical News], today published by the Polish Mathematical Society. Both Prace and Wiadomości were financed from Dickstein's private fund until 1939. He moreover made a lot of efforts to manage the translation of various mathematical works into Polish.

${ }^{[n]}$ Witold Wilkosz (1891-1941). He was a classmate of Stefan Banach. In 1910, he began his studies of classical philology at Jagiellonian University. In 1912, he changed to mathematics at the university in Turin. After the outbreak of the war, he continued his mathematical studies in Cracow and finished them by defending a PhD in 1918 and then a habilitation in 1920. From 1920, he was a professor at Jagiellonian University. Besides his strictly scientific works in mathematical analysis, geometry and logic, he wrote textbooks and popular books and was very active in popularizing mathematics. He contributed also to the development of radio technology and radiophony. He was arrested by the Germans in November 1939, but released due to health problems. He died in Cracow in March 1941.

[o] Stefan Jan Kempisty (1892-1940). In 1909, he went to Paris, where he studied mathematics for four semesters. Between 1915 and 1917, he studied mathematics at Jagiellonian University. In 1919, he defended a PhD, in 1924 a habilitation. He became a professor at Stefan Batory University in Vilnius and his works were in the theory of functions. He died in prison in Vilnius.

${ }^{[\mathrm{p}]}$ Antoni Bonifacy Przeborski (1871-1941). Between 1889 and 1904, he studied mathematics at the University of Kiev. In 1904, he spent one term in Göttingen to follow Hilbert's lectures. In 1905, he became a professor at the University of Kharkov. In 1922, he came back to Poland and became a professor at Warsaw University until 1939. He also gave lectures at the Polytechnic School in Warsaw. His works deal with mathematical analysis, theoretical mechanics and the calculus of variations.

[q] Andrzej Koźniewski (1907-1939). He was a mathematician and actuary.

${ }^{[r]}$ Stefan Kwietniewski (1874-1940). He studied at the ETH in Zurich and at the universities of Munich and Göttingen. In 1902 he defended a PhD in Zurich. Between 1907 and 1909, he read lectures at the Society for Scientific Courses [Towarzystwo Kursów Naukowych] - a private high school founded in 1905 in Warsaw. Between 1915 and 1939, he was a lecturer in geometry at Warsaw University. He translated several mathematical treatises into Polish. He died suddenly in Warsaw in 1940.

[s] Stanisław Zaremba (1863-1942). Between 1881 and 1886, he followed technical studies in the Saint Petersburg Institute of Technology. From 1886, he studied mathematics in Paris, defending a $\mathrm{PhD}$ in 1889 at the Sorbonne. Between 1892 and 1900, Zaremba taught in grammar schools in three cities in 
the South of France: Digne, Nîmes and Cahors. Between 1900 and 1935, he was a professor of Jagiellonian University and after retiring he was nominated honorary professor. He died in Cracow in 1942. Zaremba was one of the pioneers of modern mathematics in Poland. His works covered mathematical analysis and the applications of mathematics, especially in physics (he focused particularly on second order partial differential equations). He was also interested in logic as well as in the philosophy and methodology of mathematics.

${ }^{[t]}$ Stefan Mazurkiewicz (1888-1945). He studied in Cracow, Munich, Göttingen, and Lvov. In 1913, he defended a PhD in Lvov, in 1919 a habilitation in Cracow. Between 1915 and 1939, he was a professor at the University of Warsaw. Mazurkiewicz served as vice-rector and dean. He was one of the cofounders of the journal Fundamenta Mathematicae. Between 1920 and 1939, he collaborated with the Cipher Bureau (and in particular, he broke the cipher used by the Soviet Army in 1920). His works were in topology, mathematical analysis and probability. He died in June 1945.

${ }^{[u]}$ Stefan Banach (1892-1945). Between 1910 and 1914, Banach studied at the Polytechnic School in Lvov, but as he did not complete his studies, he learned mathematics mostly as an autodidact. Banach's mathematical talent was discovered in 1916 by Hugo Steinhaus. In 1920, he defended a PhD in Lvov, in 1922 a habilitation. Between 1922 and 1939, he was a professor at the Jan Kazimierz University in Lvov. During the Soviet occupation between 1939 and 1941, he was a professor of the Ukrainian University in Lvov and served as dean. Between 1941 and 1944, he was a feeder of lice at the Research Institute of Typhus and Viruses established by Rudolf Weigel in Lvov, a position that probably saved him as well as several other academics ${ }^{1}$. After 1944, Banach was again a professor at the Ukrainian University, but he died in August 1945. In the 1920s, Banach created a new discipline - functional analysis - and became one of the world's leading mathematicians of his time.

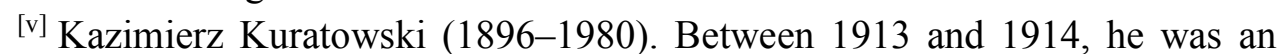
engineering student at the University of Glasgow in Scotland. After the opening of the Polish university in Warsaw, he studied mathematics there after 1915. In 1921, he defended a PhD and a habilitation. Between 1923 and 1927, he was deputy professor of mathematics at Warsaw University. Between 1927 and 1933, he was a professor of mathematics at the Lvov Polytechnic Institute, for which he served twice as the dean. Between 1934 and 1939 and then again between 1945 and 1966, he was a professor at Warsaw University. His works are in topology, descriptive set theory and measure theory. In 1981, a prize was established bearing his name for exceptional achievements in mathematics by people under the age of 30 .

${ }^{[\mathrm{w}]}$ Karol Borsuk (1905-1982). Between 1923 and 1927, he studied mathematics at Warsaw University. Between 1927 and 1930, he was a teacher in a gymnasium. In 1929, he became an assistant at Warsaw University. In 1930, he 1957).

${ }^{1}$ On Weigel and his Institute, see A. Wincewicz, M. Sulkowska \& S. Sulkowski, Rudolph Weigl (1883- 
defended a PhD supervised by Stefan Mazurkiewicz and in 1934 a habilitation. Between 1934 and 1969, he was a professor at Warsaw University, but left the university as a protest against a surge of anti-Semitic campaigns in Poland. Until 1975, he was a professor at the Mathematical Institute of the Polish Academy of Sciences. His works are in topology and he also founded shape theory, the theory of retracts and the cohomology theory.

${ }^{[x]}$ Hugo Steinhaus (1887-1972). In 1905 he began to study mathematics in Lvov. During the years 1906-1911 he studied at the university in Göttingen under the guidance of David Hilbert and Felix Klein. In 1911, he obtained a $\mathrm{PhD}$ in Gottingen, in 1917 a habilitation in Lvov. During the years 1920-1939, he was a professor at Jan Kazimierz University in Lvov. During World War II, he hid himself under the name of Grzegorz Krochmalny. From 1945, he stayed in Wrocław. He was a professor at Wrocław University and a member of the Polish Academy of Sciences. He died in 1972. His work was in the theory of trigonometric and orthogonal series as well as summability, probability theory, measure theory, set theory, and the applications of mathematics in various domains, especially in biology, medicine and statistics. He was involved in the popularisation of mathematics and also known for his aphorisms.

${ }^{[y]}$ Franciszek Leja (1885-1979). From 1904 to 1909, he studied mathematics at Jan Kazimierz University in Lvov and then taught in gymnasiums. During the years 1912-1913, he continued his studies in Paris and London, and then obtained his PhD in 1916 in Cracow. Starting in 1916, he worked at Jagiellonian University. In 1919, he was a co-founder of the Polish Mathematical Society. In 1922, he obtained his habilitation and during the years 1923-1936 he worked as a professor at the Polytechnic School in Warsaw. During the years 19361960, he was a professor at Jagiellonian University. His works mainly concern group theory, power series, analytic functions, and complex analysis. He also introduced the concept of the topological group.

${ }^{[z]}$ Mieczysław Biernacki (1891-1959). During the years 1909-1911, he studied chemistry at Jagiellonian University and from 1911 to 1914 he studied mathematics in Paris. During World War I, he served in the French army. During 1921-1923, he continued his studies of mathematics in Paris, and in 1923 he became licencié ès sciences, before obtaining in 1928 a doctorate (docteur ès sciences mathématiques) in Paris. His master and later a friend was Paul Montel. During the years 1929-1939, he was professor at Poznan University, then from 1944 to 1959 professor at the Maria Curie-Skłodowska University in Lublin. He died in Lublin. Most of his mathematical work deals with the theory of analytic functions and the theory of differential equations.

\section{References}

Audin M., Fatou, Julia, Montel: the great prize of mathematical sciences of 1918, and beyond, Springer Science \& Business Media, Berlin 2011.

Barbut M., Locker B. \& Mazliak L., Paul Lévy and Maurice Fréchet: 50 years of correspondence in 107 letters, Springer Science \& Business Media, Berlin 2013. 
Beeler R. A. \& Norwood R., Polish Mathematics in the First Half of the $20^{\text {th }}$ Century in: Mathematical Scientist 39, 2014, pp. 1-10.

Charle Ch. \& Telkes E., Les professeurs de la Faculté des sciences de Paris, dictionnaire biographique 1901-1939, INRP \& CNRS, Paris 1989.

de Broglie L. \& al., Paul Montel, mathématicien niçois, Ville de Nice, Nice 1966.

Davies N., God's Playground. A History of Poland, vol. 1: The Origins to 1795, vol. 2: 1795 to the Present, Oxford University Press, Oxford 2005.

Domoradzki S. \& Stawiska M., Polish mathematicians and mathematics in World War I. Part I: Galicia (Austro-Hungarian Empire) in: Studia Historiae Scientiarum 17, 2018, pp. 23-49.

Domoradzki S. \& Stawiska M., Polish mathematicians and mathematics in World War I. Part II: Russian Empire in: Studia Historiae Scientiarum 18, 2019, pp. 55-92.

Duda R., Fundamenta Mathematicae and the Warsaw school of mathematics in: C. Goldstein, J. Gray \& J. Ritter (eds.), Mathematical Europe, MSH, Paris 1996, pp. 479-498.

Duda R., Leaders of Polish mathematics between the two world wars in: Commentationes Mathematicae 53, 2013, pp. 5-12.

Duda R., Polish mathematicians against the background of Polish history in the nineteenth and twentieth centuries in: Antiquitates Mathematicae 10, 2016, pp. 89-119.

Duda R., One hundred years of the Polish Mathematical Society in: Antiquitates Mathematicae 12, 2018, pp. 3-30.

Gispert H., La France mathématique, SMF \& SFHST, Paris 1990 [augm. $2^{\text {nd }}$ ed.: La France mathématique de la Troisième République avant la Grande Guerre, SMF, Paris 2016].

Gispert H. \& Leloup J., Des patrons des mathématiques en France dans l'entre-deux-guerres in: Revue d'histoire des sciences 62, 2009, pp. 39-117.

Jaëck F., From Fundamenta Mathematicae to Studia Mathematica: The Renaissance of Polish mathematics in light of Banach's publications 1919-1940 in: L. Mazliak \& R. Tazzioli (eds.), Mathematical Communities in the Reconstruction After the Great War 1918-1928: Trajectories and Institutions, Springer International Publishing, Basel 2021, pp. 253-276.

Kieniewicz S. \& al., History of Poland, PWN, Warszawa 1979.

Kuratowski K., Wacław Sierpiński (1882-1969) in: Acta Aritmetica 21, 1972, pp. 1-5.

Kuratowski K., Pół wieku matematyki polskiej (1920-1970), Wiedza Powszechna, Warszawa 1973.

Kuratowski K., A Half Century of Polish Mathematics: Remembrances and Reflections, PWN \& Pergamon Press, Warszawa \& Oxford 1980.

Leray J., My friend Julius Schauder in: W. Forster (ed.), Numerical Solutions of Highly Nonlinear Problems, North-Holland Publ. Comp., Amsterdam 1980, pp. 427-439.

Mandelbrojt S., Notice nécrologique sur Paul Montel in: Comptes Rendus de l'Académie des sciences Paris Vie Académique 280, 25/1974, pp. 186-188. 
Mauldin R. D., The Scottish Book. Mathematics from the Scottish Cafe, Birkhäuser, Boston 1981.

Mawhin J., A tribute to Juliusz Schauder in: Antiquitates Mathematicae 12, 1/2018, pp. 229-257.

Mazliak L., A whole new vigor: About Montel's book "Les mathématiques et la vie" (1947) in: Teaching mathematics and computer science 18, 2020, pp. $51-60$.

Mazliak L. \& Shafer G., What does the arrest and release of Emile Borel and his colleagues in 1941 tell us about the German occupation of France? in: Science in Context 24, 4/2011, pp. 587-623.

Mazliak L. \& Tazzioli R. (eds.), Mathematical Communities in the Reconstruction After the Great War 1918-1928: Trajectories and Institutions: Trajectories and Institutions, Springer International Publishing, Basel 2021.

Mostowski A., Travaux de W. Sierpiński sur la théorie des ensembles et ses applications in W. Sierpiński, Euvres choisies, vol. 2, PWN - Editions Scientifiques de Pologne, Warszawa 1975, pp. 9-13.

Montel P., Notice nécrologique sur Waclaw Sierpinski in: Comptes Rendus de l'Académie des sciences Paris Vie Académique 270 (12 janvier 1970), pp. 32-33 [available online at https://www.academie-sciences.fr/pdf/eloges/ sierpinski_cr1970.pdf, retrieved on Oct 14., 2021].

Murawski R., Mathematics and logic in Polish encyclopedias published during the interwar period in: L. Mazliak \& R. Tazzioli (eds.), Mathematical Communities in the Reconstruction After the Great War 1918-1928: Trajectories and Institutions, Springer International Publishing, Basel 2021, pp. 89-117.

Olszewicz B., Lista strat kultury polskiej, Wydawnictwo S. Arcta, Warszawa 1947.

Reddaway W. \& al. (eds.), The Cambridge History of Poland, Octagon Books, New York 1971.

Roos H., A History of Modern Poland: From the Foundation of the State in the First World War to the Present Day, Eyre and Spottiswoode, London 1966.

Steinhaus H., Mathematician for All Seasons. Recollections and Notes, vol. 2: (1945-1968), (eds.) R. G. Burns, I. Szymaniec \& A. Weron, Birkhäuser, Basel 2016.

Tatarkiewicz W., Etyczne podstawy rewindykacji i odszkodowań in: W. Tatarkiewicz, Pisma z etyki i teorii szczęścia, (ed.) P. J. Smoczyński, Zakład Narodowy im. Ossolińskich Wydawnictwo, Wrocław - Warszawa - Kraków 1992, pp. 113-122 [Engl. transl. Ethical Grounds for Retribution and Compensation [1945], transl. Z. Nierada in: Organon 43, 2011, pp. 187-197].

Wandycz P., The Price of Freedom: A History of East Central Europe from the Middle Ages to the Present, Routledge, London 1992.

Wincewicz A., Sulkowska M. \& Sulkowski S., Rudolph Weigl (1883-1957) a scientist in Poland in wartime plus ratio quam vis in: Journal of Medical Biography 15, 2/2007, pp. 111-115.

Zamoyski A., The Polish Way: A Thousand-Year History of the Poles and their Culture, Franklin Watts, New York 1987. 